\title{
Intersections
}

Canadian Journal of Music

Revue canadienne de musique

\section{Heather MacLachlan. 2011. Burma's Pop Music Industry: Creators, Distributors, Censors. Rochester: University of Rochester Press. 272 pp. ISBN 978-1580463867}

\section{Tom Artiss}

Volume 32, numéro 1-2, 2012

URI : https://id.erudit.org/iderudit/1018585ar

DOI : https://doi.org/10.7202/1018585ar

Aller au sommaire du numéro

Éditeur(s)

Canadian University Music Society / Société de musique des universités canadiennes

ISSN

1911-0146 (imprimé)

1918-512X (numérique)

Découvrir la revue

Citer ce compte rendu

Artiss, T. (2012). Compte rendu de [Heather MacLachlan. 2011. Burma's Pop Music Industry: Creators, Distributors, Censors. Rochester: University of Rochester Press. 272 pp. ISBN 978-1580463867]. Intersections, 32(1-2), 231-233. https://doi.org/10.7202/1018585ar

Copyright @ Canadian University Music Society / Société de musique des universités canadiennes, 2013
Ce document est protégé par la loi sur le droit d'auteur. L'utilisation des services d'Érudit (y compris la reproduction) est assujettie à sa politique d'utilisation que vous pouvez consulter en ligne.

https://apropos.erudit.org/fr/usagers/politique-dutilisation/ 


\section{BOOK REVIEWS / RECENSIONS}

Heather MacLachlan. 2011. Burma's Pop Music Industry: Creators, Distributors, Censors. Rochester: University of Rochester Press. 272 pp. ISBN 978-1580463867.

Canadian ethnomusicologist Heather MacLachlan's first book is a rich and accessible ethnographical account of contemporary musical activity in Yangon, Burma. Continuing a recent trend in ethnomusicology that gives attention to syncretic musical forms and practices in post-colonial settings, the volume is as much to be recommended for what it does not do as for what it does. Instead of focusing on pre-colonial, pre-globalization traditional musical practices (e.g., Maha Gita, ethnic Karen music), which, as she makes clear, are still very much alive, MacLachlan carefully examines the particular musical products of the intersection of Burmese and Western cultures, namely Burmese popular music, locally known as stereo.

In addition to a descriptive account of the various modes and contexts of production and consumption of stereo in Burma, MacLachlan tackles dominant cultural discourses that dismiss Burmese popular music as "watered-down ... covers of rock relics" (5). She argues that in spite of its undeniable debt to Western musical styles and technologies, stereo is not simply the product of one-way cultural hegemony. If a Burmese song sounds like a poor imitation of a Western original, it is not because the local music industry has been coopted by Hollywood-based multinationals (5). On the contrary, she claims, by acquiring and reproducing Western popular music in defiance of government restrictions and regulations-sometimes at great personal risk-Burmese musicians are exercising considerable agency and ingenuity.

Chapter 1 draws on ethnographic material to paint a picture of a socially engaged, economically self-sufficient musical community that works within a repressive political system in order to change it. In one ethnographic vignette, MacLachlan offers a day-in-the-life account of a Yangon music studio to show how music-making reflects broader social dynamics. It is an evocative description of interpersonal relations between musicians, singers, studio engineers, producers, composers, and arrangers-some of whom perform more than one role-that also bleed into social life in tangible and intangible ways. The nine-story building that houses the studio appears as a microsystem of sociomusical activity: a café on the ground floor serves as a hangout for musicians, some of whom also occupy apartments on the upper floors. The example of one young up-and-comer, Pretty Boy Taylor, who lives with his family in the building, leaves the impression of a social environment that not only draws musicians to it but also produces them. In the process of demonstrating how studio 
dynamics mirror wider social formations, several social dynamics emerge. Notably, women are generally restricted to singing roles because of a stigma associated with playing instruments, while Buddhists are under-represented in the music industry because, unlike Christians, music and singing does not play a prominent role in their religious ceremonies.

In chapter 2 MacLachlan examines both the music and the live performance contexts in which it appears. Music concerts in Yangon typically involve a mixture of cover songs (copy thachin) and original numbers (own tune). But MacLachlan notes that, in spite of the prominence of these two genres, in practice music is more commonly categorized by themes in the lyrics. Distinctions based on authenticity are further tempered by the fact that copy thachin lyrics are usually translated into Burmese. MacLachlan pursues the question of musical originality with a superb literature review, distilling the genealogy of the relevant popular music scholarship into a few key moments and applying them to the Burmese musical scene (63-67). It is, she concludes, precisely the "self-conscious modeling of local artistic expression on foreign originals that is, ironically, the most salient 'local' aspect of the Burmese scene" (72).

In chapters 3 and 4 , the internalization of music in Burma is considered from two contrasting perspectives: bottom-up and top-down. The first of these draws from material collected using participant-observation methods. Referencing a particular recording session-to which she contributed a keyboard track-MacLachlan highlights several intercultural differences in order to ground wider Burmese social dynamics that accompany the acquisition of music skills and knowledge. One of these concerns a dichotomization of talent and practising/rehearsing, which produces an inverse relation in locally constituted conceptions of musicality between effort and ability. Simply put, "good" musicians have a gift from God and do not need to practise. It is a fascinating ethnographic addition to ongoing related concerns in musicology and ethnomusicology, notably those delineated by Henry Kingsbury, whom she astutely acknowledges $(82,83)$. After unpacking the contrast, MacLachlan suggests that in order to continue the struggle against religiously rooted beliefs and practices, progressive music teachers "will need to acknowledge that the current norm is the norm in part because it has certain advantages [e.g., pedagogical and economic]" (108). She offers instead that "spending more time working in groups and experimenting with music would probably lead to more innovation in pop musicians' output" (108). MacLachlan uncharacteristically veers toward prescription here and, by pathologizing a putative lack of innovation, reveals a possible tension in her own thesis about which I will say a few more words at the end.

The challenge facing Burmese musicians that MacLachlan's corrective addresses is fleshed out in the next chapter and concerns the degree to which institutions foster or even afford innovation and creativity. With a meticulous application of Richard Peterson's six-facet analytics of cultural production to the Burmese music industry, MacLachlan explains that while the Big Four multinational recording companies may stifle innovation in Western societies, for all the reasons Peterson suggests, the Burmese case proves that their 
absence does not necessarily produce opposite results. If one of the Big Four labels were to establish a presence in Burma operating as an oligarchy, she argues, "it would offer Burmese pop musicians much more financial stability than the musicians currently enjoy ... [and] would likely give musicians contracts and pay them large advances and royalties. The musicians would therefore have more time to experiment in the studio and would likely be more willing to take artistic risks" (140).

Chapter 5 examines the relationship between government censors and music creators. After another simultaneously thorough and succinct review of the literature on music and power (from Adorno through Lockard, Rybach, Chang, Godden, Middleton, Walser and Malm, to Breen, Negus, and Hayes), MacLachlan settles on James Scott's theory of public and hidden transcripts to analyze power relations in Burmese popular music culture. Specifically, she illustrates how Scott's four strategies (submission, defiance, subversion, and avoidance)-deployed by peasants and farmers to resist strong centralized/ imperialist state powers-are also applied effectively in urban settings and at many levels of society, not just by marginalized groups.

MacLachlan explains that she came to her topic after working in refugee camps on the Thai-Burma border in 2001. Her interest continued throughout her doctoral studies at Cornell University, where she wrote about the music of a Burmese diaspora in Indianapolis, Indiana. It has carried over into her research as faculty member of the Music Department at the University of Dayton, culminating in the scholarship presented in this volume. Empirically, Burma's Pop Music Industry is comprehensive and nuanced, demonstrating a deep appreciation for and skilful employment of ethnographic methods. In her scholarship, MacLachlan also brings to bear an impressive command of the breadth and depth of popular music studies to her topic, demonstrated clearly by her extension of non-music-related theoretical frameworks such as those of Peterson and Scott.

I would, however, return to what appears to be an analytical ambivalence, one that is not articulated explicitly but resurfaces throughout the text. Specifically, the pathologization of a lack of innovation in the Burmese popular music scene (see chapters 2, 3, and 4) is puzzling, given the emphasis she places, first, on reclaiming ingenuity and creativity from cultural commentators (see Introduction), and second, on understanding "copies" of Anglo-American forms in terms of a distinct Burmese "cultural logic" (see Conclusion, 176). My query is less with the tension itself; good ethnographies such as MacLachlan's almost always bring paradoxes and contradictions to the surface. But the omission of it as a site of inquiry leaves the reader to do work that the author could do much better. That said, MacLachlan's book is a valuable addition to the field of popular music studies and promises to be especially generative to anyone interested in cross-cultural musical hybridity or socio-musical dynamics in non-democratic states. 